\title{
NILAI KARAKTER DALAM TEKS LAGU BATAK TOBA SEBAGAI BAHAN AJAR MATA PELAJARAN BAHASA INDONESIA KELAS VIII SMP
}

\author{
Meilani Sinaga ${ }^{1}$, Stepani Naibaho $^{2}$ \\ Universitas Prima Indonesia ${ }^{1}$, Universitas Prima Indonesia ${ }^{2}$ \\ pos-el: meilanisinaga01@gmail.com ${ }^{1}$, fannynaibaho2@gmail.com ${ }^{2}$
}

\begin{abstract}
ABSTRAK
Hasil temuan ini memiliki tujuan mendeskripsikan peranan dan nilai karakter yang terdapat pada teks lagu batak toba dalam nilai pendidikan diterapkan untuk bahan ajar bahasa Indonesia terutama pada siswa kelas VIII SMP. Metode untuk mendapatkan hasil temuan ini menggunakan metode observasi lapangan dan wawancara yang dilakukan dengan cara membawa lembar kerja pada saat dilakukan wawancara untuk mendapatkan hasil data yang fakta. Salah satu langkah untuk memperoleh hasil, peneliti memilih jenis penelitian yang paling tepat ialah jenis penelitian kualitatif. Berdasarkan hasil yang di dapat peneliti memperoleh tiga nilai karakter dalam teks lagu batak toba yang berjudul "boru buha baju" meliputi nilai karakter manusia kaitannya dengan Tuhan, nilai karakter manusia kaitannya dengan kepribadian, nilai karakter antara manusia kaitannya dengan masyarakat. Nilai karakter tersebut mencakup beberapa nilai-nilai yaitu nilai rasa syukur, berdoa, pengelolaan gender, komitmen, kesetiakawanan sosial, kesopansantunan, gotong royong dan nilai kedamaian.
\end{abstract}

\section{Kata Kunci : Nilai Karakter, Lagu Batak Toba, Pembelajaran Bahasa Indonesia.}

\section{ABSTRACT}

These findings have the aim of describing the role and value of the characters contained in the Batak Toba song text in the educational value applied to Indonesian language teaching materials, especially for class VIII junior high school students. The method for obtaining these findings is using field observations and interviews conducted by bringing a worksheet at the time of the interview to obtain factual data results. One of the steps to obtain results, researchers choose the most appropriate type of research is the type of qualitative research. The results obtained by the researchers obtained three character values in the text of the Batak Toba song entitled "boru buha clothes" including the value of human character with God, the value of human character in the text, the value of human character based on society. The character values include several values, namely the value of gratitude, prayer, gender management, commitment, social solidarity, politeness, mutual cooperation and values.

\section{Keywords: Character Values, Toba Batak Song, Indonesian Language Learning.}

\section{PENDAHULUAN}

Karakter sama dengan wujud tingkah laku yang dapat di lihat dari perbuatan atau sifat yang dapat manusia terapkan dalam segala tindakan di dalam kehidupannya sehari-hari, seperti tingkah laku yang ditunjukkan dengan menghormati orang lain, bertanggung jawab atas perilaku yang di perbuat, bahkan karakter yang baik lainnya. Salah satu yang dapat dilihat dari karakter seseorang terlihat dari sifat dan perilaku.
Sifat dan perilaku seorang menunjukkan baik dan buruknya kepribadian terhadap diri sendiri. Pembentukan pribadi karakter seorang anak dapat dikembangkan melalui Pendidikan karakter. Pendidikan karakter akan menunjukkan tingkah laku yang bersifat baik. Keberhasilan seorang pendidik dapat dilihat dari sebuah karakter yang dimilikinya dalam kehidupan sehari-hari.

Pada masa-masa ini, masih banyak kejahatan yang dilakukan oleh seorang 
anak di luar ajaran orang tua. Hal itu terjadi karena adanya pengaruh dari lingkungan sekitar yang membuat seseorang berubah dari jalannya. Tidak hanya itu juga, banyak anak yang mengambil sifat yang buruk dari orang tua anak tersebut. Selain itu, masalah karakter yang ada pada anak dapat dipengaruhi oleh didikan orang tua dari anak itu sendiri juga.

Orang tua yang menunjukkan sifat yang buruk di depan anak anaknya maka seorang anak lebih gampang untuk meniru sifat yang di perlakukan orang tua. Oleh karena itu, sebagai panutan di dalam keluarga orang tua harus mampu memberikan yang terbaik dan cerminan yang baik di depan seorang anak. Dengan begitu anak dapat meniru perbuatan ataupun sifat yang di dapat di dalam sebuah keluarganya. Lalu seorang anak mampu berinteraksi yang baik di lingkungan sekitarnya dan menirukan perbuatan apa yang dilihat dari dalam lingkungan keluarganya.

Pendidikan karakter yang di temukan dalam budaya batak toba memiliki nilai-nilai berharga yang dapat ditanamkan. Suku Batak memiliki berbagai macam suku yang ada yaitu, Suku Pakpak, Suku Simalungun, Suku Karo, Suku Mandailing, Suku Batak Toba, dan Suku Dairi.

Suku Batak Toba terkenal dengan beberapa budaya yang kental dan unik menarik seperti tari-tarian, kerajinan tangan, seni sastra hingga seni rupa yang menyatu. Salah satu bentuk dari kebudayaan itu adalah lagu .

Lagu dapat menceritakan atau menyampaikan perasaan seseorang terhadap orang lain. Sebuah lagu juga dapat di kombinasikan melalui perpaduan antara musik dan suara. Sebuah lagu memiliki rangkaian kata indah yang di mana dapat membuat pendengar terhibur bahkan mengandung perasaan yang adanya tawa, kesedihan, dan kekaguman pada lirik-lirik yang ada pada lagu. Berdasarkan pada penelitian ini, memanfaatkan teks lagu dapat dibuat untuk pembelajaran di Sekolah Menengah Pertama (SMP). Hal ini dapat terjadi karena adanya kesesuaian antara media yang digunakan dalam pembelajaran dengan materi pembelajaran Bahasa Indonesia .Teks lagu dapat membuat tanggapan terhadap ekspresi seseorang dengan apa yang ditulis dan dirasakan. Hal itu sejalan dengan menurut (Daemono, 2016) mengatakan bahwa teks lagu merupakan ekspresi seseorang tentang sesuatu hal yang mudah dilihat, didengar, maupun dialaminya, lagu merupakan kata-kata dan bahasa untuk menciptakan daya Tarik dan ke khasan terhadap lirik atau syair.

Menerapkan media pembelajaran berupa lirik lagu dapat memicu peserta didik berfikir kritis untuk ide tersebut dapat dituangkan kedalam tulisan, terutama ke dalam sebuah materi pembelajaran Bahasa Indonesia itu sendiri. Berdasarkan uraian diatas, penting untuk dilakukannya penelitian lebih lanjut dengan judul “ Nilai Karakter dalam Teks Lagu Batak Toba Sebagai Bahan Ajar Mata pelajaran Bahasa Indonesia Kelas VIII SMP ”.

\section{METODE PENELITIAN}

Peneliti mendeskripsikan bentuk penelitian menurut tempat pengumpulan data fakta yaitu penelitian kualitatif deskriptif dengan cara penelitian lapangan. Penelitian ini dilakukan dengan cara langsung kelapangan. selanjutnya menyatukan data fakta yang penting ataupun dibutuhkan. Dengan cara ini, peneliti dapat melihat keadaan secara cepat dan langsung, akhirnya diperoleh dan diyakinkan bahwa data yang didapatkan fakta atau benar-benar terjadi.

Metode penelitian kualitatif ini akan mempermudah mendapatkan data yang bersifat mendalam terutama ikut terlibatnya peneliti di lapangan tersebut. Di dalam penelitian ini, diharapkan 
untuk mendapatkan data fakta yang berhubungan langsung dengan masyarakat yang berada di kecamatan Pangururan. Setelah dapat beberapa bukti data penelitian, peneliti dapat menyusun dengan mudah hasil penelitiannya.

Teknik yang dipakai untuk mendapatkan data fakta dalam penelitian ini adalah observasi, wawancara. Salah satu teknik yang digunakan di dalam penelitian melakukan observasi untuk mendapatkan informasi yang fakta. Peneliti langsung terjun turun untuk kelapangan secara langsung yang di mana dilakukan meneliti langsung lingkungan sekitar, kemudian menulis hal-hal yang perlu yang berhubungan dengan data yang diperoleh, jadi dapat diketahui bahwa data yang ditemukan oleh peneliti benar-benar fakta dan nyata dengan apa yang terjadi.

Observasi dilakukan di Pangururan kabupaten Samosir. Observasi dapat dilakukan untuk memperoleh data yang akurat dan situasi yang ada di lingkungan masyarakat. Observasi juga dilakukan untuk mengetahui nilai karakter dalam lagu Batak toba sebagai bahan ajar mata pelajaran Bahasa Indonesia.

Teknik pengumpulan data peneliti digunakan adalah wawancara apabila seorang peneliti untuk menemukan berbagai permasalahan yang harus diteliti. Teknik wawancara juga merupakan teknik yang sangat banyak digunakan dan membutuhkan waktu yang cukup lama. Teknik wawancara dilakukan untuk mendapatkan responden yang mendalam lagi dan data informasi yang lebih.

Kegiatan wawancara yang dilakukan peneliti adalah kepada warga masyarakat yang berada di wilayah Pangururan Kecamatan Samosir guna untuk memperoleh informasi yang lebih mendalam pada peranan nilai untuk bahan ajar seperti mata pelajaran Bahasa
Indonesia.

\section{HASIL DAN PEMBAHASAN}

Peranan Nilai Karakter Dalam Teks Lirik Lagu Sebagai Bahan Ajar Kelas VIII SMP sangat penting untuk pembentukan karakter pada setiap karakter anak peserta didik, dan guruguru mampu membina karakter seorang anak menjadi contoh dan mengajarkan kepada anak akan hal yang baik sehingga anak bisa mengenal perbuatan baik maupun yang tidak baik, guru semangat dalam mengajar anak didik jika anak memiliki karakter yang baik, dan lirik teks lagu sangat bermanfaat juga di lakukan sebagai bahan ajar dalam mata pelajaran bahasa Indonesia guru lebih mudah mengarahkan siswa dengan makna yang terkandung di teks lagu tersebut.

Teks lagu itu juga mengandung makna yang sangat penting dalam membentuk sebuah karakter pada anak didik. Teks lagu batak juga menggambarkan nasehat-nasehat yang cocok untuk sebagai contoh ajaran untuk peserta didik di sekolah. Lirik teks lagu setiap bait mengandung makan yang mendalam itu dapat di ajarkan kepada anak dan dapat juga diterapkan sebagai contoh pembelajaran dalam pembuatan puisi, dari teks lagu siswa mudah untuk merangkai kata-kata dengan teks lagu batak dan mudah untuk menentukan tema karena setiap baik lirik lagu sudah mengandung makna.

Peran guru proses pembelajaran dalam pembentukan karakter dengan menjadi teladan dengan cara mampu menguasai dan memahami bahan ajar yang akan di ajarkan dan berjalan secara efektif. Guru harus mampu menciptakan suasana yang aktif dalam proses pembelajaran dengan cara guru bercerita dengan tema nasehat juga dapat memotivasi siswa. Peserta didik pasti semangat jika guru memberikan nasehat dengan cara bercerita siswa akan lebih 
memahami lagi akan perilaku yang baik dan sopan santun.

Peranan Nilai Karakter Dalam Teks Lirik Lagu Sebagai Bahan Ajar Kelas VIII SMP

Peran nilai karakter itu sangatlah penting dalam membentuk suatu karakter pada anak atau pun siswa, kita ketahui dalam lirik teks lagu batak toba cocok untuk dibuat sebagai bahan ajar seperti bahasa Indonesia sebab dalam pelajaran tersebut mempelajari puisi, pantun dll.

Lirik lagu bisa dibuat sebagai puisi yang mengandung makna tertentu, baitbait suatu lagu bisa dijadikan sebagai pantun. Bait-bait lirik lagu dirangkai menjadi suatu puisi sebaliknya juga puisi bisa di jadikan menjadi teks lagu.

\section{Nilai Karakter Manusia Hubungannya Dengan Tuhan Pada Teks lirik lagu Boru \\ Buha Baju}

Nilai Karakter Manusia

hubungannya dengan Tuhan iman yang ada pada diri manusia bentuk rasa pengakuan bisa juga sebagai memberikan pujian terhadap nikmat yang Tuhan berikan yang disertai ketaatan kepada Tuhan. Orang yang bersyukur atas nikmat Tuhan akan membuat ia mendapat menikmati yang lebih banyak.

Nilai pembentukan karakter yang ada pada karakter manusia hubungannya dengan Tuhan yaitu:

(1) Nilai Rasa Syukur

(2) Nilai Berdoa

Pada lirik lagu Richard Sianturi berjudul boru buha baju di dalamnya terdapat nilai karakter manusia hubungannya dengan

Tuhan terdapat pada lirik :

1). lirik ke-4 (lagu Boru Buha Baju)

"jala tongtong diramoti Tuhan I"

"dan selalu diberkati Tuhan"

Dalam kata "diramoti" yang artinya orang tua bersyukur atas keberkatan Tuhan terhadap putrinya dari kecil sampai besar seperti ini. mengajarkan anak untuk selalu mengucapkan syukur kepada Tuhan setiap dia di permudah dalam hal yang di lakukan nya seperti mendapat juara kelas atau peringkat $1 \mathrm{di}$ dalam kelas, kita harus mengejar dia mengucapkan syukur kepada Tuhan.

2. Lirik ke-10 (lagu Boru Buha Baju)

"boanonku do ho ditangiangku"

"aku akan selalu mendoakanmu"

Dalam kutipan kata ditangiangku” yang artinya orang tua yang selalu mendoakan putri pertamanya setiap saat dengan keadaan apa pun. sebagai orang tua harus mengarahkan anak setiap hari minggu mengikuti ibadah ke gereja. Dengan beribadah anak pasti akan tahu dengan hal berdoa. Hal ini juga akan timbul rasa percaya diri dan kuat mental ini termasuk dalam wujud nilai pembentukan karakter manusia berhubungan erat dengan Tuhan.

Nilai Karakter Manusia Hubungannya Dengan Kepribadian pada Teks Lirik Lagu Boru Buha Baju Nilai karakter manusia berhubungan erat dengan kepribadian terlihat dalam proses karakter seseorang terbentuknya secara sadar maupun tidak sadarnya.

Pembentukan Karakter manusia itu berawal dari diri sendiri dulu. Dua nilai pembentukan karakter yang ada pada karakter manusia hubungannya dengan kepribadian seperti :

1) Nilai Pengelolaan Gender

2) Nilai Komitmen

Pada lirik lagu Richard Sianturi berjudul boru buha baju di dalamnya terdapat nilai karakter manusia hubungannya dengan kepribadian terdapat pada lirik :

1. lirik ke-15 (lagu Boru Buha Baju)

"ho do boru sibaen sangap I diahu"

"kau yang akan memberi kehormatan bagiku"

Dalam lirik lagu ini mengandung arti yaitu anak pertama perempuan yang membuat orang tua tenang dan anak pertama perempuan yang mulia di mata orang tuanya. Perbedaan terlihat dengan perbedaan peran, sifat bahkan tingkah laku yang tumbuh dengan diri sendiri. 
2. Lirik ke-9 (lagu Boru Buha Baju)

"pos ma roham inang"

"tenangkan hatimu"

Dalam lirik ini mengandung makna yaitu sebagai anak perempuan harus percaya, dan menguatkan hatinya kepada kedua orang tuanya dan kelak akan sukses. Komitmen adalah janji terhadap diri sendiri dan bagi orang lain. Di lingkungan sekolah komitmen dalam peserta didik juga ada itu di sebut dengan komitmen belajar artinya sebuah janji untuk melakukan yang terbaik untuk disekolah, contohnya mempelajari halhal baru, mengerjakan tugas, perhatian dan hormat kepada guru dan taat akan aturan disekolah.

\section{Nilai Karakter Manusia Hubungannya Dengan Masyarakat pada Teks Lirik Lagu Boru Buha Baju}

Karakter manusia sama dengan sifat yang baik harus sesuai dengan nilai masyarakat dan juga orang di lingkungan sekeliling. Pembentukan karakter manusia dalam bermasyarakat pasti memiliki sifat dan tingkah lagu atau disebut juga dengan kehidupan dalam bersosial. Nilai pembentukan karakter yang ada pada karakter manusia hubungannya dengan masyarakat terdapat empat nilai di dalamnya yaitu :

1) Nilai Kesetiakawanan sosial

2) Nilai Kesopansantunan

3) Nilai Gotong Royong

4) Nilai Kedamaian

Lagu ciptaan Richard Sianturi berjudul Boru Buha Baju di dalamnya terdapat nilai karakter manusia berhubungan erat dengan masyarakat terletak pada lirik :

1. Lirik ke-5 (lagu Boru Buha Baju)

" boru panggoaran ku nalagu”

"putri pertamaku yang baik"

Dalam lirik boru buha bajuku yaitu anak perempuan pertama yang artinya contoh untuk gambaran buat anak yang di bawahnya mengarahkan, menirukan sifat baiknya kepada anak yang di bawah nya supaya mereka bisa sama untuk membahagia kan orang tua pada kelak nanti. Makhluk yang setia adalah manusia yang selalu bertahan baik pada sesamanya. Perilaku setiakawan ini suatu hal perbuatan untuk menjaga teman baik di saat keadaan susah maupun keadaan senang ini mencerminkan nilai kesetiakawanan sosial. 2. Lirik ke-15 (lagu Boru Buha Baju)

"ho do boru sibaen sangap i diahu"

"kau yang akan memberi kehormatan bagiku"

Dalam lirik sangap artinya anak yang mulia di mata orang tua atau derajat yang paling tinggi yang perlu di junjung tinggikan orang tua. Seorang anak juga harus saling menghargai, yang muda menghargai yang tua sebaliknya dengan yang tua menghargai memberikan teladan. sopan santun adalah tingkah laku yang ramah dan sopan terhadap teman sekeliling. Sopan santun ini sangat penting diterapkan dalam peserta didik, terutama juga dalam masyarakat karena sikap sopan ini sangat erat hubungan dengan masyarakat ini terwujud menggambarkan nilai kesopansantunan.

3. Lirik ke-6 (lagu Boru Buha Baju)

"boru panggoaranku nalagu"

"putriku yang pertama yang baik"

Dalam lirik lagu ini mengandung arti anak perempuan pertama yang akan ditiru olah adik-adiknya jadi harus bisa lebih baik supaya bisa sebagai contoh untuk adik-adiknya dan sebagai panutan juga bagi adik-adiknya. gotong royong merupakan keinginan pencapaian hasil yang maksimal seperti usaha yang dilakukan hati tulus dan ikhlas. Menumbuhkan rasa tolong menolong saling membantu sesama manusia, dan dapat mempererat tali persaudaraan. Seperti diterapkan dalam lagu Boru Buha Baju anak pertama yang mejadi panutan dan contoh buat adik-adiknya agar mereka menjadi satu hati, hal ini terungkap terhadap nilai gotong royong.

4. Lirik ke-8 (lagu Boru Buha Baju)

"anggiat dapot nasininta ni roham"

"semoga kau dapat meraih cita-citamu"

Dalam lirik lagu nasininta mengandung makna orang tua menginginkan anak 
perempuan nya harus bisa sukses meraih cita-cita dan keingannya dan ini akan selalu menjadi teladan. Damai dalam kehidupan merupakan sebuah harmoni alami antara manusia di mana tidak ada pertentangan atau konflik. Damai itu sama dengan ketenangan hati karena memiliki hubungan bersih dengan Tuhan. Damai juga memberikan pengajaran pentingnya hidup yang berakter baik, lirik lagu ini menggambar nilai kedamaian.

\section{KESIMPULAN}

Berdasarkan hasil permasalahan dan analisis hasil pembahasan khusus dapat disimpulkan bahwa lagu ciptaan Richard Sianturi berjudul "Boru Buha Baju" terdapat tiga gambaran karakter yaitu (1) nilai karakter manusia berhubungan erat dengan Tuhan (2) nilai manusia hubungannya sama kepribadian (3) nilai karakter manusia hubungannya dengan masyarakat. peranan nilai karakter dalam teks lirik lagu sebagai bahan ajar kelas VIII SMP sangat penting untuk pembentukan karakter pada setiap karakter anak peserta didik, dan sudah menerapkannya sebagai bahan ajar seperti dalam mata pelajaran bahasa Indonesia, contohnya membuat puisi dari lirik teks lagu batak toba.

Nilai-nilai teks lagu dalam pembentukan nilai pendidikan karakter terhadap siswa, guru sudah mampu membina, mendidik karakter pada setiap murid untuk bisa menjadi patokan atau contoh bagi murid-murid yang baik dan santun di lingkungan pekarangan sekolah.

\section{DAFTAR PUSTAKA}

Sujana,Gede. Peranan Pendidikan Karakter Dalam Membangun Perilaku Pembelajaran.Dwijendra: jurnal Widya Acharya. 2014.
Lubis, Mawardi.2009. Evaluasi Pendidikan Nilai Yogjakarta: Pustaka Pelajar.

Hidayatullah, M Furqon. 2011. Implementasi Nilai Karakter: Membangun Peradaban Bangsa. Surakarta: Yuma Pustaka.

Riwanty, Oska. 2012. Penerapan Dalam Metode Nilai Pendidikan Bahasa dan Sastra. Surakarta: Yuma Pustaka.

Majid, Abdul. 2008. Perencanaan Pembelajaran. Bandung: PT. Remaja Rosdakarya.

Wibintaro, Rifan. 2015. Manejemen Pendidikan Karakter di Sekolah Kelas VII SMP. Yogyakarta: Pustaka Pelajar.

Hastono, Rifai. 2013. Strategi Pembelajaran Pendidikan Nilai Karakter. Yogyakarta: Ar-Ruzz Media.

Sriwilujeng, dyah. 2017. Panduan Implementasi Penguatan Pendidikan Karakter. Bandung: Erlangga.

Abidin, Yudi. 2012. Pembelajaran berbahasa berbasis pendidikan karakter. Bandung Refika Aditama.

Zainal Aqib, dkk. 2011. Panduan dan Aplikasi Karakter, Bandung : Yrama Widya.

Noviana Fitria, Veti. 2019. Lirik Lagu sebagai Media Pembelajaran Cerita Fantasi di SMP Negeri 2 Gatak Sukoharjo. Surakarta: Universitas Muhammadiyah Surakarta. 